\title{
PELAYANAN DAN SARANA KESEHATAN DI JAWA ABAD XX
}

\author{
Oleh: Dina Dwi Kurniarini, Ririn Darini, Ita Mutiara Dewi ${ }^{1}$
}

\begin{abstract}
Abstrak
Artikel tentang Pelayanan dan Sarana Kesehatan di Jawa Abad Ke-20 ini berusaha untuk menguraikan faktor-faktor penyebab, perkembangan dan dampak dari keberadaan pelayanan dan sarana kesehatan di abad ke-20. Kajian tentang kesehatan di Jawa abad ke-20 ini menunjukkan bahwa (1) faktor-faktor yang menyebabkan perkembangan fasilitas dan sarana kesehatan di Jawa pada abad ke-20 terutama kebijakan pemerintah pada masanya (baik masa kolonial maupun kemerdekaan) dan perkembangan ilmu kedokteran atau kesehatan; (2) Perkembangan pelayanan dan sarana kesehatan di Jawa dapat ditelusuri dari keberadaan tenaga kesehatan dan pendidikannya serta rumah sakit sebagai fasilitas kesehatan utama; (3) Sedangkan dampak dari perkembangan pelayanan dan fasilitas kesehatan yaitu wabah penyakit yang dapat teratasi dan meningkatnya pertumbuhan penduduk sebagai akibat dari sedikit meningkatnya taraf kesehatan masyarakat Indonesia
\end{abstract}

Kata Kunci: sejarah kesehatan, pelayanan, sarana

\section{A. Pendahuluan}

Pada masa kolonial, tingkat kesejahteraan penduduk bumiputra sangat memprihatinkan termasuk kondisi kesehatan. Saat itu cukup berkembang wabah penyakit menular antara lain: malaria, pes, kolera dan cacar yang menyebabkan angka mortalitas yang tinggi. Meskipun perawatan kesehatan untuk daerah jajahan Belanda sudah dimulai sejak Politik Etis, namun kualitas kesehatan masyarakat masih rendah. Perkembangan perekonomian Hindia Belanda hanya menggambarkan keberhasilan Belanda dalam misinya mendapatkan keuntungan besar. Tujuan Pemerintah Belanda di Indonesia meliputi dual mandate yang berupa pengembangan sumber daya alam atau La richessenaturalle, tetapi pemerintah Belanda juga mempunyai konsekuensi terhadap orang-orang taklukannya untuk mengembangkan La richevace atau kesejahteraan penduduk ${ }^{2}$, seperti dalam layanan pemerintah untuk membantu pertanian pribumi, perawatan kesehatan masyarakat, pendidikan, kegiatan misi dan sebagainya. Kebijakan tersebut memaksa pengusaha terutama pengusaha perkebunan untuk memperhatikan kesehatan pekerja sesuai dengan misi Belanda.

\footnotetext{
${ }^{1}$ Para penulis adalah staf pengajar di Prodi Ilmu Sejarah, Fakultas Ilmu Sosial, Universitas Negeri Yogyakarta.

2 J.S. Furnivall. Nederlands Indie A Study of Plural Economy (Cambridge: University Press, 1967), hlm. 346.
} 
Sarana kesehatan yang tersedia belum mencukupi karena terapi medis Barat mulai masuk nusantara bersamaan dengan kedatangan VOC yang melakukan perdagangan di wilayah ini. Spesialis medis yang dibawa ke Indonesia adalah ahli bedah yang dapat meng-obati penyakit ${ }^{3}$ Dokter-dokter Belanda di Hindia Belanda bekerja di kapal maupun di darat.

Setelah VOC mendirikan benteng di Batavia pada tahun 1612, perawatan pasien baru dimulai dan pendirian rumah sakit pertama di daerah pantai pada tahun $1626 .{ }^{4}$ Bentuk pelayanan kesehatan kompeni ini menyebar ke kepulauan Nusantara mengikuti meluasnya teritorial perdagangan kompeni. Bangunan rumah sakit dari bambu dan batu didirikan di tempat pemukiman atau markas utama VOC. Dokter dan rumah sakit mengutamakan pelayanan kesehatan bagi pegawai VOC yang harus segera disembuhkan agar dapat bekerja kembali.

Untuk mempergunakan jasa rumah sakit, pasien harus membayar sendiri kecuali pegawai VOC yang dibayarkan oleh VOC. Oleh karena penduduk yang sakit tidak mampu membayar, maka rumah sakit hanya dimanfaatkan oleh VOC, sehingga rumah sakit hanya berlatar belakang ekonomi bukan kemanusiaan ${ }^{5}$ Faktor ini merupakan salah satu penyebab kenapa penduduk belum berobat ke dokter atau rumah sakit.

Berdasarkan latar belakang tersebut, maka artikel ini akan membahas tentang kesehatan masyarakat Jawa yang meliputi: (1) Faktor-faktor yang mempengaruhi pelayanan dan sarana kesehatan di Jawa pada abad ke-20; (2) Perkembangan pelayanan dan sarana kesehatan di Jawa pada abad ke-20 ; (3) Dampak dari pelayanan dan sarana kesehatan di Jawa pada abad ke-20.

\section{B. Faktor-faktor yang Mempengaruhi Pelayanan dan Sarana Kesehatan di Jawa pada Abad XX}

\section{Kebijakan Pemerintah}

Sejak awal abad ke-20 perhatian pemerintah kolonial Belanda meningkat dalam mengontrol penyakit epidemik seperti kolera dan pes. Terutama karena pes, pemerintah kolonial mengintensifkan kegiatannya dalam bidang kesehatan umum dan higienitas. Terdapat dua perkembangan penting dalam perbaikan ini. Pertama, perkembangan pesat dalam ilmu medis yang yang memungkinkan memutuskan sebab beberapa penyakit tropis dan mengambil tindakan preventif atau melakukan tindakan-tindakan kuratif. Kedua, perubahan bertahap dalam ideologi kolonial yang dikenal dengan sebutan Politik Etis yang menghasilkan kebijakan yang lebih humanis terhadap penduduk pribumi. Ini berarti bahwa lebih banyak uang dikeluarkan untuk kesejahteraan. Dalam bidang kesehatan

\footnotetext{
${ }^{3}$ Peter Boomgard, et al., Health Care in Java Past and Present, (Leiden: KITLV Press, 1996), hlm. 24.

${ }^{4}$ Ibid., hlm. 24-25.

${ }^{5}$ Ibid.
} 
publik hasil dari kebijakan baru ini cukup nyata. Terdapat dua lembaga yang secara institusional diberi tanggung jawab langsung mengenai masalah kesehatan. Kedua lembaga tersebut adalah Burgerlijk Geneeskundige Dienst (BGD - Layanan Kesehatan Sipil) dan Dienst der Volksgezondheid (DVG - Layanan Kesehatan Publik). Lembaga-lembaga ini selain melakukan tindakan-tidakan kesehatan kuratif dan preventif, juga menerbitkan publikasipublikasi. Publikasi-publikasi itu antara lain Mededeelingen van den Burgerlijk Geneeskundigen Dienst (Komunikasi-komunikasi Layanan Pengobatan Sipil terutama dipublikasikan dalam Geneeskundig Tijdschrift voor Nederlandsch-Indie). Yang berkaitan dengan pelayanan pes, misalnya, terbit laporan-laporan yang dicetak sebagai lampiran pada Geneeskundig Tijdschrift voor Nederlandsch-Indie. ${ }^{6}$

Kebijakan kesehatan yang berkaitan dengan peningkatan kesejahteraan penduduk adalah dengan menambah personel kesehatan baik yang terlibat dalam upaya preventif maupun dalam tindakan kuratif. Menurut Boomgaard, paling tidak terdapat dua kebijakan kesejahteraan yang mempunyai dampak besar bagi tingkat kualitas kesehatan penduduk Jawa pada masa itu. Pertama, menjelang tahun 1930-an, kebijakan peningkatan kesejahteraan telah didesain dengan pendekatan yang sinergis untuk sejumlah permasalahan sekaligus. Maksudnya satu kebijakan mempunyai beberapa sasaran kesejahteraan sekaligus, misalnya mengenai proyek pembangunan irigasi yang mempunyai dampak positif baik bagi sektor pertanian maupun dalam sektor kesehatan masyarakat. Hal tersebut bisa terjadi karena dengan pembangunan saluran irigasi yang baik di satu sisi akan meningkatkan produksi pertanian sementara pada satu sisi lainnya dapat mengendalikan pengembangbiakan larva nyamuk yang menyebabkan penyakit malaria. Kedua, bahwa solusi kekurangan dana telah dapat diselesaikan dengan penggunaan teknologi modern pada awal abad ke-20. Beberapa percobaan yang dilakukan pada masa itu dengan obat-obatan yang digunakan untuk tanaman dan hama sawah (tikus) secara tidak langsung telah membantu menjaga kesehatan manusia. Sesudah perang dunia I, DDT sering digunakan dalam keperluan di atas. ${ }^{7}$

Kebijakan yang mempunyai dampak besar bagi perluasan pelayanan kesehatan adalah pemberian subsidi kesehatan kepada rumah sakit Hindia Belanda. Tujuan kebijakan ini agar pelayanan kesehatan tidak hanya dinikmati oleh golongan tertentu, seperti yang terjadi pada masa-masa sebelumnya, namun juga dapat dinikmati oleh semua lapisan masyarakat yang membutuhkan.

Sampai awal abad ke-19, pendanaan rumah sakit diperoleh dari subsidi penguasa dan dana yang diambil dari pasien. Pada saat itu juga telah berkembang pemberian pelayanan

\footnotetext{
${ }^{6}$ Mumuh Muhsin Z., Bibliografi Sejarah Kesehatan Pada Masa Pemerintahan Hindia Belanda, Paramita, Jurnal Sejarah dan Pembelajaran Sejarah Vol. 22, No. 2 - Juli 2012, hlm. 9

${ }^{7}$ Peter Boomgaard, "Upliftment down the drain? Effect of Welfare Measures in Late Colonial Indonesia", dalam Jan-Paul Dirkse, Frans Husken and Mario Rutten (ed.) Development and Social Welfare: Indonesia's Experiences under the New Order, (Leiden: KITLV Press, 1993), hlm. 253.
} 
rumah sakit yang tergantung kepada kebutuhan dan kemampuan pasien, terutama yang berhubungan dengan diet yang diterima pasien. Sementara rumah sakit swasta, seperti rumah sakit milik perkebunan atau pertambangan dan rumah sakit keagamaan, harus membiayai sendiri semua kebutuhannya. Namun sejak tahun 1906 pemerintah kemudian memberikan subsidi secara teratur kepada rumah sakit baik milik pemerintah maupun swasta dalam bentuk bantuan tenaga, peralatan, obat-obatan maupun dana kas. ${ }^{8}$

Sejak tahun 1906, kebijakan subsidi kesehatan mulai dilakukan secara teratur dengan peraturan-peraturan yang lebih jelas bila dibandingkan masa sebelumnya. Selain itu, pada kurun waktu tersebut merupakan pertama kali dilakukan klasifikasi dan kategorisasi terhadap keberadaan rumah sakit swasta. Secara garis besar subsidi kesehatan yang diberikan pemerintah tersebut dapat berupa dana kas, obat-obatan, peralatan rumah sakit, maupun berupa gaji dokter dan paramedis yang bekerja pada sebuah rumah sakit swasta. ${ }^{9}$

Pada dasarnya di masa colonial, pembiayaan kesehatan pemerintah bersumber dari pajak dan hasil bumi yang dihasilkan dari bumi Indonesia. Warga pribumi hanya berperan sebagai pengguna jasa pelayanan kesehatan yang disediakan oleh pemerintah Hindia Belanda. Pada masa ini Pemerintah Hindia Belanda tidak dapat menjamin pelayanan kesehatan berbasis kemasyarakatan yang bisa memberikan jaminan bahwa setiap penduduk memiliki status kesehatan yang baik. Pemerintah Hindia Belanda hanya mementingkan pelayanan kesehatan bagi para pegawai pemerintah Hindia Belanda, Militer belanda dan pegawai perusahaan milik pemerintah pada masa itu.

Salah satu perkembangan penting bidang kesehatan pada masa kemerdekaan adalah konsep Bandung ( Bandung Plan ) pada tahun 1951 oleh dr. J. Leimena dan dr. Patah. Konsep ini memperkenalkan bahwa dalam pelayanan kesehatan masyarakat, aspek kuratif dan rehabilitatif tidak bisa dipisahkan. Tahun 1956, dr. J. Sulianti mengembangkan konsep baru dalam upaya pengembangan kesehatan masyarakat, yaitu model pelayanan bagai pengembangan kesehatan masyarakat pedesaan di Indonesia. Konsep ini memadukan antara pelayanan medis dengan pelayanan kesehatan masyarakat pedesaan. Proyek ini dilaksanakan di beberapa seperti Sumatera Utara, Lampung, Jawa Barat, Jawa Tengah, Yogyakarta, Jawa Timur, Bali dan Kalimantan Selatan ${ }^{10}$. Kedelapan wilayah tersebut merupakan daerah percontohan sebuah proyek besar yang sekarang dikenal dengan nama pusat kesehatan masyarakat (puskesmas).

Pada masa kemerdekaan dan orde lama, pembiayaan kesehatan pemerintah pada waktu

\footnotetext{
${ }^{8}$ Staatsblad van Nederlandsch Indie No. 276 Tahun 1906 dalam Baha'uddin, Pelayanan Kesehatan Rumah Sakit Pada Masa Kolonial, t.t. t.p., diakses dari https://www.academia.edu/4598877/Pelayanan_Kesehatan_Rumah_Sakit_Pada_Masa_Kolonial

${ }^{9}$ Baha'uddin, Politik Etis Dan Pelayanan Kesehatan Masyarakat Di Jawa Pada Awal Abad XX: Studi Kebijakan Kesehatan Pemerintah Kolonial Hindia Belanda, Makalah Konferensi Nasional Sejarah VIII, 14 17 November 2006, hlm.7.

${ }^{10}$ Notoatmojo, op. cit.
} 
itu bersumber hampir seluruhnya dari anggaran pemerintah. Kebijakan pembiayaan kesehatan masyarakat sepenuhnya berada dalam kendali penuh pemerintahan Presiden Soekarno.

Tabel 1. Perubahan Pola Pembiayaan Kesehatan Di Indonesia

\begin{tabular}{|l|l|l|}
\hline Komponen yang dikaji & Masa Kolonial & $\begin{array}{l}\text { Masa Kemerdekaan dan Orde } \\
\text { Lama }\end{array}$ \\
\hline Jumlah Anggaran & Tidak diketahui & Tidak diketahui \\
\hline Sistem Perencanaan Anggaran & $\begin{array}{l}\text { Diatur Pemerintah Hindia } \\
\text { Belanda }\end{array}$ & $\begin{array}{l}\text { Berubah seiring perubahan peta } \\
\text { politik }\end{array}$ \\
\hline Pengambil Keputusan & Pemerintah Hindia Belanda & Pemerintah Orde Lama \\
\hline Pengaruh Politik & $\begin{array}{l}\text { Kerajaan Belanda Berkuasa } \\
\text { penuh }\end{array}$ & Sering berubah \\
\hline $\begin{array}{l}\text { Kebijakan Pembiayaan } \\
\text { Kesehatan }\end{array}$ & $\begin{array}{l}\text { Pelatihan Dukun Bayi, pendirian } \\
\text { STOVIA dan sekolah dokter } \\
\text { lainnya, pembangunan rumah } \\
\text { sakit dan fasilitas kesehatan lain }\end{array}$ & $\begin{array}{l}\text { Konsep Bandung Plan (cikal bakal } \\
\text { puskesmas), laboratorium kesehatan }\end{array}$ \\
\hline Sasaran Utama & Warga Belanda, Militer Belanda & Pejabat pemerintah, sebagian rakyat \\
\hline Kondisi Keuangan Negara & Sangat miskin & Miskin \\
\hline
\end{tabular}

Sumber : Diolah dari berbagai sumber.

\section{Perkembangan Ilmu Kedokteran (Kesehatan)}

Obat-obat asli atau jamu di Indonesia merupakan unsur penting dalam kehidupan masyarakat dan sampai sekarang masih digunakan di samping obat- obat modern; penjual jamu gendong tidak hanya terdapat di desa-desa, tetapi banyak terlihat di kota. Selain penjual jamu gendong tersebut terdapat ahli-ahli patah tulang, ahli-ahli pijat dan toko-toko obat tradisional baik yang menjual obat-obat asli Indonesia, obat-obat asli Cina maupun asli India.

Pengobatan tradisional melalui jamu dapat dikatakan pula sebagai tonggak kebangkitan pengobatan Eropa:

The trade in herbs and spices, which started in the sixteenth century, made the European diet much tastier. It also provided physicians with substances they could use in the treatment of disease. In fact, the Renaissance of European medicine in the seventeenth century was mostly based on the herbs and spices and on the medical insights of traditional healers from India and the Indonesian archipelago. ${ }^{11}$

Namun menurun sejak adanya penemuan modern seperti teori Pasteur, pembedahan dan teknologi sinar X, dapat dikatakan pengobatan tradisional tergantikan oleh pengobatan modern

However, the interest of European physicians and pharmacists in Indonesian herbal medicine decreased significantly after 1900, after several new discoveries and technological breakthroughs had been made, such as Pasteur's germ theory, a-septic surgery and the X-ray machine. When western medicine appeared to become successful, physicians no longer looked for alternatives. Instead, they wanted to spread western medical insights to the East. ${ }^{12}$

Pada zaman penjajahan Belanda, ilmu kedokteran dari Eropa dibawa ke Indonesia oleh

\footnotetext{
${ }^{11}$ Hans Pols, The Triumph of Jamu, Inside Indonesia 100: Apr-Jun 2010, hlm. 5.

${ }^{12} \mathrm{Ibid}$, hlm. 6.
} 
dokter-dokter yang didatangkan untuk melayani kesatuan- kesatuan militer Belanda dan dipergunakan pula untuk pegawai-pegawai sipil mereka. Kekhawatiran tentang penjalaran penyakit cacar yang sangat berbahaya mendesak Belanda untuk mendidik tenaga pembantu untuk melaksanakan vaksinasi cacar yaitu mantri.

Perkembangan ilmu kedokteran dan evolusinya dapat dikaitkan dengan ruang lingkup kesehatan masyarakat secara umum yang mencakup lima tahapan yaitu zaman kesehatan empiris, zaman ilmu dasar, zaman ilmu klinis, zaman ilmu kesehatan masyarakat dan zaman ilmu politik, sebagai berikut:

Tabel 2. Ruang Lingkup Kesehatan Masyarakat

\begin{tabular}{|c|c|c|c|c|c|}
\hline $\begin{array}{c}\text { Unsur } \\
\text { Pengembangan }\end{array}$ & $\begin{array}{l}\text { Empirical } \\
\text { Health Era } \\
<1850\end{array}$ & $\begin{array}{c}\text { Basic Science } \\
\text { Era } \\
(1850-1900)\end{array}$ & $\begin{array}{c}\text { Clinical } \\
\text { Science Era } \\
(1900-1950)\end{array}$ & $\begin{array}{l}\text { Public Health } \\
\text { Science Era } \\
(1950-1900)\end{array}$ & $\begin{array}{c}\text { Political } \\
\text { Science Era } \\
>1900\end{array}$ \\
\hline $\begin{array}{ll}\text { Titik Berat } \\
\text { Pelayanan }\end{array}$ & $\begin{array}{l}\text { Gejala- } \\
\text { Gejala } \\
\text { Penyakit }\end{array}$ & $\begin{array}{l}\text { Bakteri \& } \\
\text { Penyakit }\end{array}$ & $\begin{array}{l}\text { Pasien } \\
\text { (Penderita) }\end{array}$ & $\begin{array}{l}\text { Masyarakat } \\
\text { penduduk }\end{array}$ & $\begin{array}{l}\text { Masyarakat dan } \\
\text { Lingkungan } \\
\text { Kesehatan }\end{array}$ \\
\hline $\begin{array}{l}\text { Cara } \\
\text { Penyelanggaraan } \\
\text { Pendidikan }\end{array}$ & $\begin{array}{l}\text { Mengikuti } \\
\text { petunjuk } \\
\text { secara } \\
\text { mutlak dari } \\
\text { pengajar }\end{array}$ & $\begin{array}{l}\text { Diagnosa } \\
\text { Laboratorium }\end{array}$ & $\begin{array}{l}\text { Polikinilk/ Balai } \\
\text { Pengobatan } \\
\text { sebagai tempat } \\
\text { praktik }\end{array}$ & $\begin{array}{l}\text { Kelinik \& balai } \\
\text { Kesehatan } \\
\text { Masyarakat } \\
\text { dan } \\
\text { masyakrakjat } \\
\text { sebagai tempat } \\
\text { praktik }\end{array}$ & $\begin{array}{l}\text { RS Pendidikan } \\
\text { dan daerah } \\
\text { lokasi praktik }\end{array}$ \\
\hline $\begin{array}{l}\text { Penelitian dan } \\
\text { Pengembangan }\end{array}$ & $\begin{array}{l}\text { Pengalaman } \\
\text { Empiris } \\
\text { (historical) }\end{array}$ & $\begin{array}{l}\text { Pengembangan } \\
\text { Laboratorium }\end{array}$ & $\begin{array}{l}\text { Pengembangan } \\
\text { Iptek } \\
\text { Kedokteran }\end{array}$ & $\begin{array}{l}\text { Pengembangan } \\
\text { masyarakat } \\
\text { dan dengan } \\
\text { pengembangan } \\
\text { tolok ukur dan } \\
\text { kreteria- } \\
\text { kreteria }\end{array}$ & $\begin{array}{l}\text { Selain } \\
\text { pengembangan } \\
\text { Iptek Kedokteran } \\
\text { dan masy, juga } \\
\text { dikembangankan } \\
\text { bidang ilmu } \\
\text { yang lain seperti } \\
\text { ekonomi, sosial } \\
\text { dan politik. }\end{array}$ \\
\hline
\end{tabular}

Sumber: Basavanthappa (2008: 35)

\section{Pelayanan dan Sarana Kesehatan Abad XX}

\section{Tenaga Medis dan Pendidikannya}

Tenaga medis merupakan aktor yang terlibat langsung dalam pelayanan kesehatan. Kebijakan pemerintah kolonial diorientasikan untuk memfasilitasi pendidikan para tenaga medis misalnya melalui pelatihan bidan atau dukun bayi, pendirian STOVIA dan sekolah dokter lainnya. Sampai pertengahan abad ke-19, praktis pelayanan kesehatan modern di Indonesia mutlak milik orang Eropa terutama kalangan militer. Masyarakat pribumi baru mulai berperan dalam pelayanan kesehatan ketika pemerintah Belanda menyadari keterbatasan sumber daya manusia medis yang dimilikinya. Kondisi tersebut paling tidak terjadi pada dua keadaan, pertama pada suatu kondisi ketika terjadi wabah suatu penyakit di daerah tertentu 
yang membutuhkan penanganan cepat sedangkan dokter yang dimiliki oleh pemerintah sangat terbatas. Kedua, mobilisasi dokter Belanda sangat terbatas di daerah perkotaan saja sedangkan biasanya sebagian besar wabah penyakit terjadi di wilayah pedesaan. Oleh karena itulah, untuk pemerintah Hindia Belanda dengan terpaksa membuat kebijakan untuk mencetak profesi baru di kalangan masyarakat pribumi dalam bidang kesehatan yaitu Dokter Jawa dan mantri kesehatan. Jika Dokter Jawa harus dicetak melalui pendidikan formal, mantri kesehatan cukup dengan pelatihan-pelatihan khusus sesuai dengan bidang penyakit atau aspek kesehatan lain yang menjadi tanggung jawabnya. Adapun perkembangan pendidikan dokter Jawa pada abad ke-19 dan ke-20 dapat diamati sbb:

Tabel 3. Pendidikan Dokter Jawa

\begin{tabular}{|c|c|c|c|c|}
\hline Tahun & $\begin{array}{l}\text { Lama } \\
\text { Studi }\end{array}$ & Syarat Masuk & Bhs Pengantar & Lulusan/Gelar \\
\hline 1851 & 2 tahun & $\begin{array}{c}\text { Bisa menulis dan } \\
\text { bicara bhs Melayu }\end{array}$ & Bhs Melayu & $\begin{array}{c}\text { Vaccinateur/Dokter } \\
\text { Jawa }\end{array}$ \\
\hline 1863 & 3 tahun & sda & Bhs Melayu & $\begin{array}{c}\text { Dokter dgn } \\
\text { pengawasan/Dokter } \\
\text { Jawa }\end{array}$ \\
\hline 1875 & 7 tahun & sda & Bhs Belanda & sda \\
\hline 1881 & 8 tahun & Lulus ELS & Bhs Belanda & sda \\
\hline 1898 & \multicolumn{4}{|c|}{ Nama sekolah diganti dengan School tot Opleiding van Inlandsche Geneeskundigen } \\
\hline 1902 & \multicolumn{4}{|c|}{ Nama sekolah diganti dengan STOVIA } \\
\hline 1902 & 9 tahun & Lulus ELS & Bhs Belanda & Inlandsch Arts \\
\hline 1913 & 10 tahun & Lulus ELS & Bhs Belanda & Indisch Arts \\
\hline 1913 & \multicolumn{4}{|c|}{ Di Surabaya di buka NIAS dg kurikulum 10 tahun } \\
\hline 1924 & 8,5 tahun & Lulus MULO & Bhs Belanda & Indisch Arts \\
\hline 1927 & \multicolumn{4}{|c|}{ Di buka GHS di Batavia } \\
\hline 1927 & 6 tahun & AMS & Bhs Belanda & Artsen \\
\hline
\end{tabular}

Sumber: Hesselink, 2009

Sedangkan jumlah tenaga medis sekitar tahun 1920 - 1933 pada dasarnya terus mengalami peningkatan sebagai berikut:

Tabel 4. Perkembangan Jumlah Tenaga Medis

\begin{tabular}{|l|c|c|c|c|}
\hline \multicolumn{1}{|c|}{ Tenaga Kesehatan } & $\mathbf{1 9 2 0}$ & $\mathbf{1 9 2 5}$ & $\mathbf{1 9 3 0}$ & $\mathbf{1 9 3 3}$ \\
\hline Dokter Pemerintah & 65 & 127 & 153 & 110 \\
\hline Dokter Pribumi Negeri & 171 & 179 & 231 & 230 \\
\hline Personel Kesehatan Lainnya & 51 & 31 & 22 & 22 \\
\hline Dokter Umum & 87 & 57 & 56 & 30 \\
\hline $\begin{array}{l}\text { Pegawai kesehatan yang dibebankan pada } \\
\text { DVG }\end{array}$ & - & 63 & 66 & 65 \\
\hline Dokter Gigi & - & 2 & 3 & 3 \\
\hline Apoteker & - & 3 & 8 & 6 \\
\hline Asisten Apoteker & - & 13 & 20 & 22 \\
\hline Perawat Berijazah Eropa & 83 & 133 & 195 & 143 \\
\hline Perawat Berijazah Pribumi & 161 & 562 & 979 & 1077 \\
\hline
\end{tabular}




\begin{tabular}{|l|c|c|c|c|}
\hline Vaccinator (Mantri) & 411 & 390 & 394 & 395 \\
\hline Calon Vaccinator (Calon Mantri) & 57 & 56 & 60 & 60 \\
\hline Bidan & 58 & 49 & 91 & 102 \\
\hline Teknisi & 28 & 21 & 10 & 7 \\
\hline
\end{tabular}

Sumber: P. Peverelli, “De Ontploiing van den Burgelijken Geneeskundingen Dienst” dalam Feestbundle Geneeskundige Tijdschrift Nederlandsch-Indie 1936, hlm. 188

Jumlah tenaga kerja kesehatan sangat erat hubungannya dengan usaha pendidikan tenaga tersebut, karena pendidikan merupakan sumber pokok dari tenaga kerja. Menurut catatan, sampai tanggal 1 Januari 1964 jumlah dokter 1.323 orang. Dari jumlah tersebut secara keseluruhan perbandingan jumlah dokter dan jumlah penduduk masih mengalami ketimpangan, karena satu dokter harus melayani 50.000 orang. Bahkan di Jawa Barat perbandingan tersebut adalah 1 dokter untuk 150.000 orang. ${ }^{13}$

Pembinaan tenaga para medis telah mencapai tahap perkembangan yang mengesankan. Di samping memperbanyak jumlah tempat pendidikan yang ada, didirikan pula berbagai macam sekolah lainnya untuk memenuhi "rising demand". Tenaga ahli farmasi (apoteker) setelah kemerdekaan hanya tercatat 27 orang yang pada umumnya merupakan orang asing. Pada 1 Januari 1964 telah ada 162 orang apoteker. Hal ini merupakan hasil yang mengesankan mengingat kondisi pada waktu itu. ${ }^{14}$

Mutu tenaga kesehatan terus ditingkatkan dengan diselenggarakannya berbagai macam pendidikan bagi tenaga kesehatan. Beberapa perkembangan sampai dengan tahun 1965 terkait sekolah kesehatan adalah sebagai berikut: ${ }^{15}$

1. Sekolah Kader Hygiene, ditambah dengan berdirinya Akademi Penilik Kesehatan didirikan di Surabaya pada tahun 1961

2. Sekolah sanitarian di Jakarta tahun 1961

3. Sekolah Kader Perawatan dan Akademi Perawatan di Jakarta tahun 1962

4. Sekolah Perawatan Anak tahun 1962

5. Sekolah Perawatan Anastesi tahun 1962

6. Sekolah Perawatan Fisioterapi tahun 1964

7. Akademi Perawatan Jurusan Kebidanan, Perwatan, dan Kesehatan Masyarakat tahun 1966 di Bandung

8. Akademi Perwatan, Nutrition, Penilik Kesehatan

9. Fakultas Kesehatan Masyarakat

\footnotetext{
${ }^{13}$ Departemen Kesehatan RI, Sejarah Kesehatan Nasional Indonesia, (Jakarta: Departemen Kesehatan RI, 1980), hlm. 98.

${ }^{14}$ Ibid.

${ }^{15}$ Ibid., hlm. 99
} 
Pada periode 1965 jumlah perawat telah mencapai 47.000 orang, bila sebelumnya pada tahun 1955 hanya berjumlah sekitar 15.000 orang yang setengahnya tidak berijazah. ${ }^{16}$ Meskipun demikian jumlah tersebut masih jauh dari cukup karena luasnya lapangan yang harus dikerjakan.

Dalam bidang pendidikan kedokteran, setelah pengakuan kedaulatan hanya terdapat 3 buah Fakultas Kedokteran di Jakarta, Yogyakarta, dan Surabaya. Pada tahun 1960 jumlah tersebut bertambah menjadi 8 buah yaitu di Bandung, Semarang, Medan, Padang, Ujungpandang. Pada tahun 1963 telah berhasil meluluskan 400 orang dokter. Secara keseluruhan pada tahun 1963 telah ada 1.225 dokter umum dan 225 dokter gigi. $^{17}$

\section{Rumah Sakit dan Fasilitas Kesehatan Lain}

Pada tahun 1641, VOC mendirikan bangunan rumah sakit permanen di kawasan yang sekarang disebut Jakarta. Rumah sakit juga dibangun di pos-pos perdagangan di luar (buitenposten). Sebelumnya, rumah sakit hanya menjadi tempat untuk mengisolasi pekerja yang jatuh sakit dan mendapat cedera. Di rumah sakit ini tidak ada perawatan dalam arti sesungguhnya. VOC juga menunjang dan memberi subsidi guna pembangunan rumah sakit pertama untuk masyarakat Cina di Jakarta, terutama untuk menampung mereka yang terlantar dan para pecandu madat. ${ }^{18}$

Setelah VOC mengalami kebangkrutan rumah sakit tersebut diambil alih oleh pihak militer. Selanjutnya mulailah sejarah pengembangan dan pembangunan jaringan rumah sakit militer pada masa pemerintahan Daendels untuk merawat tentara colonial yang sakit atau terluka dalam pertempuran. Di Jakarta, Semarang, dan Surabaya dibangun Groot-Militaire Hospitalen. Rumah sakit garnisun dibangun di dalam atau di dekat tangsi militer di kota-kota lebih kecil di Jawa, Maluku, dan pos-pos luar lainnya. Rumah sakit militer ini dibangun dengan ketentuan: bangunan luas, mudah dimasuki udara, ventilasi dan plafon bangsal, jarak penempatan tempat tidur yang cukup jauh, baju pasien dan perlengkapan tempat tidur harus sering diganti, bangsal harus bersih, makanan baik, dan pasien dipisahkan menurut jenis penyakit. ${ }^{19}$

Sejalan dengan perkembangan perusahaan perkebunan pada masa Sistem Tanam Paksa, pemerintah Kolonial mulai membangun sarana dan prasarana pendukungnya. Di antaranya adalah dibangunnya rumah sakit perusahaan perkebunan, pertambangan, dan pelayaran untuk memeriksa kesehatan tenaga kerja. Selama era politik etis, di Batavia dibangun Centraal Burgerlijk Ziekenhuis $(\mathrm{CBZ})^{20}$ yang selesai dibangun tahun 1919, disusul dengan pembangunan rumah sakit umum pemerintah di kota-kota lain. Pendidikan praktek

\footnotetext{
${ }^{16}$ Ibid.

${ }^{17}$ Ibid., hlm. 105.

${ }^{18}$ Samsi Jacobalis, Rumah Sakit Indonesia dalam Dinamika Sejarah, Transformasi, Globalisasi, dan Krisis Nasional, (Jakarta.: IDI, 2000), hlm. 5-6.

${ }^{19}$ Ibid.

${ }^{20}$ Sekarang RSUP Dr Cipto Mangunkusumo
} 
mahasiswa kedokteran (STOVIA, kemudian Geneeskundige Hoge School) yang sebelumnya dilaksanakan di rumah sakit militer ${ }^{21}$ dan rumah sakit penjara stadsverband di Glodog $^{22}$ dipindahkan ke CBZ. ${ }^{23}$

Perkembangan rumah sakit sebagai fasilitas kesehatan utama pada masa kolonial paling tidak dapat dikategorikan dalam tiga periodisasi yaitu:

a. Periode 1890 - 1910, merupakan masa transisi supremasi militer dalam pelayanan kesehatan oleh Militaire Geneeskundige Dienst (MGD) yang mulai digantikan oleh pelayanan kesehatan sipil oleh Burgerlijke Geneeskundige Dienst (BGD). Pemisahan yang nyata di antara kedua institusi kesehatan ini baru terjadi pada tahun 1911 yang diatur dalam Staatsblad tahun 1910 Nomor 648. BGD kemudian dijadikan bagian tersendiri di bawah Departement van Onderwijs en Eerendienst. Periode ini juga dicirikan dari kebijakan batig slot ke politik etis. Sehingga memunculkan fenomena baru: rumah sakit mulai banyak dikelola swasta terutama perkebunan dan misionaris.

b. Periode 1910 sampai 1930

Setelah terjadi perubahan dan BGD mulai tertata, perkembangan rumah sakit sipil berkembang pesat. Politik etis cukup berpengaruh dan pemerintah Hindia Belanda cukup terlibat aktif dalam pendirian dan pendanaan rumah sakit umum maupun memberikan subsidi pada rumah sakit swasta. Sejumlah usaha dilakukan dalam melakukan pelatihan terhadap pegawai rumah sakit. Periode ini dicirikan perkembangan yang pesat dalam jumlah rumah sakit umum negeri maupun swasta

c. Periode 1930 sampai 1942

Depresi ekonomi mendorong pemerintah memotong anggaran pendanaan public. Ter-dapat usaha untuk melakukan desentralisasi perawatan rumah sakit dan perusahaan swasta maupun yayasan mengambil alih beban finansial pelayanan kesehatan. Pemerintah mengurasi subsidi terhadap rumah sakit. Sebagai konsekuensi logis atas hal ini, jumlah rumah sakit menurun dan beberapa organisasi atau yayasan mengalami masalah dana.

Pada era Jepang, pelayanan kesehatan kepada rakyat jauh lebih buruk daripada sebelumnya, dikarenakan situasi perang dan kelangkaan sumber daya di segala bidang. Pada masa perang kemerdekaan masih dalam situasi konflik sehingga masalah kesehatan belum terlalu mendapatkan perhatian. Di daerah-daerah yang dikuasai republic kesulitan utama rumah sakit adalah kelangkaan dokter, kekurangan perawat, kekurangan sumber dana, dan kekurangan perbekalan kesehatan secara umum.

Periode 1970-an merupakan masa konsolidasi umum dan pembangunan nasional di segala bidang. Langkah-langkah strategis yang diterapkan antara lain pengembangan

\footnotetext{
${ }^{21}$ Sekarang RSPAD Gatot Subroto

${ }^{22}$ Sekarang sudah tidak ada lagi

${ }^{23}$ Ibid., hlm. 11
} 
puskesmas, peningkatan peran serta masyarakat, dan pengembangan system rujukan. Rumah sakit dijadikan sistem rujukan medis spesialistik dan subspesialistik khususnya dalam masalah penyembuhan dan pemulihan kesehatan perorangan. Pembangunan rumah sakit merupakan bagian dari rencana strategis pembangunan kesehatan nasional, di samping sebagai akibat dari berbagai dorongan atau tekanan yang terjadi karena perubahan dalam lingkungan social-ekonomi dan kependudukan, lingkungan kesehatan, dan lingkungan global. ${ }^{24}$

Rumah sakit swasta umumnya masih melanjutkan tradisi lama memberikan pelayanan sosial, sambil berusaha mempertahankan eksistensi dengan donasi dari golongan-golongan masyarakat yang mampu. Rumah sakit swasta yang ada merupakan warisan sebelum perang, umumnya didirikan oleh yayasan atau perkumpulan sosial dengan latar belakang etnis atau agama, atau didirikan sebagai unsur dari misi agama-agama tertentu. Pembangunan rumah sakit swasta yang baru dalam dekade 1950-an masih sangat langka. Sampai tahun 1974 tercatat ada 588 rumah sakit yang berada dalam tanggung jawab lembaga-lembaga pemerintah dan 92 yang ada di bawah lembaga masyarakat. ${ }^{25}$

Selain rumah sakit, pada masa penjajahan Belanda juga terdapat berbagai fasilitas kesehatan di berbagai daerah di Indonesia seperti Laboratorium Eykman di Bandung tahun 1888 yang juga berdiri di Medan, Makassar, Surabaya dan Yogyakarta. Saat wabah penyakit Pes masuk ke Indonesia pada tahun 1922 dan menjadi epidemik tahun 1933-1935 terutama di pulau Jawa, pemerintah Hindia Belanda melakukan penanggulangan dengan melakukan penyemprotan dengan DDT terhadap semua rumah penduduk dan vaksinasi masal. Begitupun saat terjadi wabah penyakit Kolera pada tahun 1927 dan $1937 .^{26}$

Era demokrasi terpimpin di Indonesia ditandai dengan dikeluarkannya Dekrit Presiden 5 Juli 1959. Dengan adanya dekrit tersebut, pada 10 Juli 1959, Kabinet Kerja Pertama dibentuk dengan Kolonel Prof. Dr. Satrio sebagai Menteri Muda Kesehatan. Pada era ini, berbagai lembaga kesehatan terutama di bidang pemberantasan penyakit telah berdiri dan tersebar di beberapa daerah di Indonesia. Lembaga-lembaga tersebut antara lain, Lembaga Eijkman (Jakarta), Lembaga Pasteur (Bandung), Lembaga Pemberantasan Penyakit Malaria (Jakarta), Lembaga Pemberantasan Penyakit Kelamin (Surabaya), Lembaga Pemberantasan Penyakit Rakyat (Yogyakarta), Lembaga Pemberantasan Penyakit Pes (Bandung) serta Lembaga Pemberantasan Penyakit Mata (Semarang). Dengan adanya lembaga tersebut, maka departemen kesehatan bertugas mengelola termasuk mengelola sekolah dan kursus kesehatan, jawatan perlengkapan, badan pengawas perusahaan farmasi (Bapphar), kedinasan, rumah sakit, serta balai pengobatan.

\footnotetext{
${ }^{24}$ Ibid., hlm. 15.

${ }^{25}$ Ibid., hlm. 62.

${ }^{26}$ Soekidjo Notoatmodjo, Promosi Kesehatan: Teori dan Aplikasi, (Jakarta: Penerbit Rineka Cipta, 2005).
} 


\section{Dampak Pelayanan dan Sarana Kesehatan}

\section{Peningkatan Taraf Kesehatan Masyarakat}

Pelayanan kesehatan kolonial pada awal abad ke-20, terutama untuk pelayanan kuratif sangat diskriminatif. Hanya sebagian kecil dari rakyat pribumi yang bisa mendapatkan akses pelayanan kesehatan ini. Ketika politik etis digulirkan, fokus perhatian pemerintah kolonial Belanda adalah bagaimana pelayanan kesehatan kolonial dapat dinikmati oleh masyarakat secara meluas. Dengan dasar pemikiran tersebut, kemudian muncul kebijakan subsidi kesehatan yang pada dekade 1910 -1920 berorientasi kepada perluasan pelayanan kesehatan kuratif dengan mendirikan banyak rumah sakit baik di Jawa maupun di luar Jawa, baik rumah sakit milik pemerintah maupun rumah sakit milik swasta. ${ }^{27}$ Hal ini menunjukkan bahwa pada dasarnya taraf kesehatan meningkat namun hanya untuk kalangan tertentu seperti para elit di Jawa, pekerja perkebunan, pegawai Belanda maupun masyarakat Belanda yang tinggal di Indonesia. Meskipun masyarakat pribumi Jawa mendapatkan penyuluhan kesehatan khususnya higieni dan sanitasi maupun mendapatkan vaksinasi cacar, namun belum menjangkau keseluruhan masyarakat secara luas.

Pada zaman Jepang, pelayanan dan sarana kesehatan cukup terbatas, masyarakat lebih banyak menggunakan obat tradisional sehingga taraf kesehatan pun bisa dikatakan tidak mengalami peningkatan atau tetap sama. Sedangkan pada zaman kemerdekaan Indonesia terutama sejak demokrasi terpimpin, pelayanan dan sarana kesehatan mulai berkembang pesat selaras dengan prinsip-prinsip kebijakan kesehatan.

\section{Wabah Penyakit Teratasi}

Usaha penanggulangan dan pemberantasan penyakit sangat beragam mengingat jenis penyakit tropis yang berkembang di Indonesia pada waktu itu juga sangat beragam. Beberapa penyakit yang sering melanda masyarakat antara lain pes, lepra, cacar, malaria, sampar, dan lain-lain. Usaha untuk menanggulangi sumber penyakit antara lain dengan memberi penyadaran kepada penduduk agar berperilaku sehat dan bersih. Untuk keperluan tersebut pemerintah membentuk lembaga propaganda kesehatan yang bernama Medisch Hygienische Propaganda. $^{28}$ Selain itu juga dilakukan perbaikan lingkungan dan perumahan yang disinyalir menjadi sarang penyakit. Kawasan yang tergenang air sebisa mungkin dikeringkan dengan cara diurug, rumah-rumah yang menjadi sarang tikus diperbaiki dinding dan atapnya. Untuk keperluan ini maka pada tahun 1914 dikeluarkan Beslit No. 36 dari Gubernur Jenderal tanggal 6 Juli 1914 yang dimuat dalam Staatsblad No. $486^{29}$. Satu tahun

\footnotetext{
${ }^{27}$ Baha'uddin, Politik Etis Dan Pelayanan Kesehatan Masyarakat Di Jawa Pada Awal Abad XX: Studi Kebijakan Kesehatan Pemerintah Kolonial Hindia Belanda, Makalah Konferensi Nasional Sejarah VIII, 14 17 November 2006, hlm. 1.

${ }^{28}$ Departemen Kesehatan RI, Sejarah Kesehatan Nasional Indonesia Jilid 1, (Jakarta: Departemen Kesehatan RI, 1978), hlm. 13.

${ }^{29}$ Besluit van den Goul lverneur-Generaal van 6 Juli 1914 No. 36 dalam Staatsblad van Nederlands-Indie No. 486
} 
kemudian terbit aturan tentang prinsip-prinsip pendirian gedung dan bangunan lainnya agar jangan sampai menjadi sarang tikus. ${ }^{30}$ Sedangkan kebijakan pemberantasan penyakit meliputi berbagai tindakan untuk penyembuhan dengan melakukan pengobatan pada pasien-pasien yang terserang penyakit tertentu.

Penelitian tentang wabah penyakit, penyebab, dan cara menanggulanginya pun sangat berkembang pada masa kolonial dan sesudahnya. Pemerintah kolonial Belanda menaruh perhatian yang sangat serius terhadap terjangkitnya penyakit tertentu di suatu wilayah. Biasanya mereka akan melakukan penelitian mendalam terhadap wilayah yang terjangkit penyakit. Sebagai contoh misalnya, pada tahun 1936 dilakukan penelitian mengenai terjangkitnya penyakit lepra di Kabupaten Gresik yang dilakukan oleh Dr. J.F. Tumbelaka bersama Dr. Tielung (diganti Dr. Darwis) dan seorang mantri bernama Martinus Wasito Soedirowijoto. Penelitian tersebut meliputi kajian laboratorium, kajian klinis dan terapi, mencatat dan mencatat seluruh kasus lepra, pengumpulan data endemik lepra, dan melakukan tindakan yang tepat kepada pasien ${ }^{31}$ Pada masa kolonial hingga kemerdekaan, pemberantasan penyakit menular dilakukan sebagai upaya preventif dan kuratif antara lain cacar, lepra, malaria, pes dan tuberkulosis.

\section{Peningkatan Jumlah Penduduk}

Motif terbesar orang-orang Eropa umumnya dan Belanda khususnya datang ke wilayah Nusantara adalah motif ekonomi. Mereka mencari dan mengusahakan komoditas pertanian yang laku di pasar Eropa. Guna mengoptimalkan hasil-hasil produksi baik secara kuantitas maupun kualitas selain dilakukan melalui perluasan area tanam dan memperbesar modal, juga yang tidak kalah penting adalah meningkatkan jumlah tenaga kerja. Hal yang terakhir ini merupakan faktor produksi yang sangat penting saat itu karena proyek-proyek kolonial lebih mengandalkan padat karya (labour intensive) daripada padat modal.

Dalam konteks inilah pemerintah kolonial menerapkan politik demografis yang pronatalis. Orientasi tidak hanya meningkatkan angka pertumbuhan penduduk melalui fertilitas, tapi juga menurunkan angka kematian (mortalitas). Jumlah penduduk dengan kualitas kesehatan yang baik merupakan mesin produksi yang sangat diandalkan untuk meningkatkan produksi pertanian, perkebunan, dan pembangunan-pembangunan infrastruktur yang dibutuhkan. Di sinilah awal keterlibatan langsung dan intensif pemerintah kolonial dalam masalah kesehatan penduduk. ${ }^{32}$

Pihak Belanda telah meningkatkan anggaran belanja untuk proyek kesehatan umum sebesar hampir sepuluh kali lipat antara tahun 1900 dan 1930. Dilakukannya program

Tahun 1914.

${ }^{30}$ Extracts uit het register der Besluiten van den Chef van den Dienst der Perbestrijding No. 425, Maart 1915.

${ }^{31}$ Orienterend onderzoek naar het voorkomen van Lepra in het Regentschap Grisse (oost-Java) 1936.

${ }^{32}$ Muhsin, op.cit. hlm. 4 
vaksinasi, kampanye anti malaria, dan perbaikan kesehatan, barangkali menyebabkan turunnya angka kematian (dan dengan demikian juga bertambahnya jumlah penduduk), walaupun angka-angka statistiknya masih diragukan. Apapun alasannya, angka kematian masih tetap tinggi. ${ }^{33}$

Angka kematian tertinggi tahun 1918 yang memakan korban puluhan ribu jiwa. Pertumbuhan penduduk yang cepat mulai terjadi setelah 1920 disebabkan telah teratasinya berbagai wabah penyakit. Sejak 1920, sebagian besar wilayah Jawa dapat terbebas dari epidemi cacar dan setelah 1928 terbebas dari wabah kolera. Pada tahun 1920, jumlah penduduk asli Jawa dan Madura mencapai sekitar 28,4 juta jiwa. Pada tahun 1920 jumlah penduduk asli Jawa dan Madura sudah mencapai 34,4 juta jiwa dan tahun 1930 menunjukkan 40,9 juta jiwa. ${ }^{34}$

Dalam masa 60 tahun terakhir antara 1930-1990 jumlah penduduk Indonesia hampir menjadi tiga (3) kali lipat. Suatu percepatan perkembangan penduduk telah terjadi di Indonesia dalam jangka waktu lima (5) dekade terakhir hingga tahun 1980. Namun pada periode 1980-1990 rata-rata perkembangan penduduk Indonesia secara keseluruhan telah menurun menjadi sekitar 2,0 persen per tahun. Rata-rata perkembangan penduduk tahunan yang sedang berlangsung dewasa ini lebih rendah di Jawa dibandingkan dengan kebanyakan pulau-pulau lain di luar Jawa.

Angka pertumbuhan penduduk Indonesia mengalami kenaikan pada periode 1965 hingga 1970, puncaknya yaitu pada tahun periode 1971 hingga 1980, dimana angka pertumbuhan penduduk sebesar 2,31\% dengan total penduduk 119.208.229 jiwa. Setelah periode ini, angka pertumbuhan penduduk Indonesia terus menurun hingga pada sensus 2010 angka pertumbuhan penduduk mencapai $1,49 \% .{ }^{35}$ Angka dari sensus penduduk pertama pada zaman orde baru yaitu tahun 1971 secara tidak langsung menunjukkan bahwa angka kematian cenderung menurun sebagai pengaruh peningkatan taraf kesehatan masyarakat Indonesia.

\section{E. Kesimpulan}

Pelayanan dan sarana kesehatan pada abad ke-20 tentunya terus meningkat dan berkembang dari tahun ke tahun seiring dengan bertambahnya jumlah penduduk Indonesia pada masa kolonial, kemerdekaan dan pasca kemerdekaan. Semakin beragamnya jenis penyakit khususnya yang berbentuk epidemi dan wabah seiring dengan kemajuan ilmu pengetahuan dan teknologi di bidang kesehatan khususnya kedokteran, keperawatan dan farmasi modern dalam mengatasi penyakit tersebut pun berkontribusi dalam perkembangan sarana dan prasarana kesehatan. Kebijakan pemerintah pun terus mengalami dinamika sesuai dengan problematika kesehatan pada masanya.

\footnotetext{
${ }^{33}$ M.C. Ricklefs, A History of Modern Indonesia since c.12, Third Edition, (Hampshire: Palgrave, 2001), hlm. 198.

${ }^{34}$ Ricklefs, op. cit., hlm. 197.

${ }^{35}$ HPEQ, Potret dan Ketersediaan Tenaga Keperawatan, (Jakarta: Ditjen Dikti Kemendikbud, 2011), hlm. 1.
} 
Rumah sakit dan berbagai fasilitas kesehatan lain dengan tenaga medis yang terus berkembang tentunya muncul untuk mengatasi problematika kesehatan yang semakin beragam tersebut dengan harapan berdampak untuk meningkatkan taraf kesehatan masyarakat sesuai dengan kepentingan pemerintah masa kolonial (yaitu ketersediaan tenaga kerja pertanian, perkebunan dan pembangunan infrastruktur) maupun benar-benar untuk kepentingan kesehatan masyarakat secara luas pada masa kemerdekaan dan pasca kemerdekaan.

\section{DAFTAR PUSTAKA}

Baha'uddin, Pelayanan Kesehatan Rumah Sakit Pada Masa Kolonial, t.t. t.p., diakses dari https://www. academia.edu/4598877/Pelayanan_Kesehatan_Rumah_Sakit_Pada_Masa_Kolonial

Baha'uddin, Politik Etis Dan Pelayanan Kesehatan Masyarakat Di Jawa Pada Awal Abad XX: Studi

Kebijakan Kesehatan Pemerintah Kolonial Hindia Belanda, Makalah Konferensi Nasional Sejarah VIII, 14 - 17 November 2006

Basavanthappa, B.T., Community Health Nursing, (New Delhi: JPBMP, 2008)

Boomgard, Peter, et al. Health Care in Java Past and Present, (Leiden: KITLV Press, 1996)

Boomgaard, Peter. "Upliftment down the drain? Effect of Welfare Measures in Late Colonial Indonesia", dalam Jan-Paul Dirkse, Frans Husken and Mario Rutten (ed.) Development and Social Welfare: Indonesia's Experiences under the New Order, (Leiden: KITLV Press, 1993)

Furnivall, .J.S. Nederlands Indie A Study of Plural Economy (Cambridge: University Press, 1967)

Hesselink, Liesbeth, Healers On Colonial Market: Natives Doctor and Midwives in Dutch East Indies (Leiden: KITLV Press, 2011)

Mumuh Muhsin Z., Bibliografi Sejarah Kesehatan Pada Masa Pemerintahan Hindia Belanda, Paramita, Jurnal Sejarah dan Pembelajaran Sejarah Vol. 22, No. 2 - Juli 2012,

Peverelli, P. "De Ontploiing van den Burgelijken Geneeskundingen Dienst" dalam Feestbundle Geneeskundige Tijdschrift Nederlandsch-Indie 1936

Pols, Hans. The Triumph of Jamu, Inside Indonesia 100: Apr-Jun 2010

Samsi Jacobalis, "Kumpulan Tulisan Terpilih Tentang Rumah Sakit Indonesia" dalam Dinamika Sejarah, Transformasi, Globalisasi dan Krisis Nasional, (Jakarta: Yayasan Penerbit IDI, 2000)

Satrio, et. al. Sejarah Kesehatan NasionalIndonesia II, III, (Jakarta: DEPKES RI, 1980)

Soekidjo Notoatmodjo, Promosi Kesehatan: Teori dan Aplikasi, (Jakarta: Penerbit Rineka Cipta, 2005)

Zondervan, Sjoerd, Hospital in Netherlands East Indies 1890 - 1940, t.t. t.p. diakses dari https://www.historici. nl/sites/default/files/The\%20Hospitals\%20of\%20NEI.pdf 